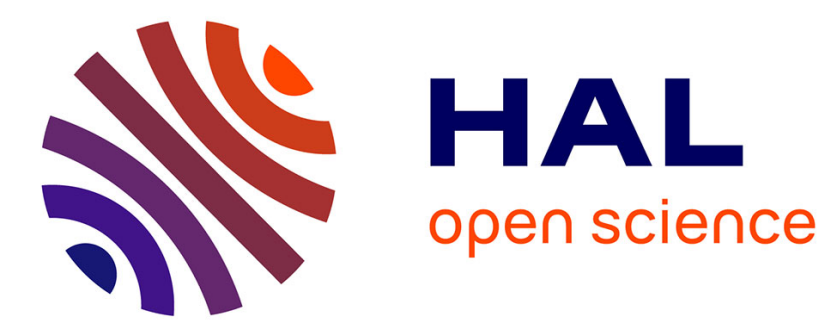

\title{
Using a 3D needle-tissue force distribution basis to optimise the design of an instrumented needle
}

Adeline L.G. Robert, Grégory Chagnon, Philippe Cinquin, Alexandre

Moreau-Gaudry

\section{- To cite this version:}

Adeline L.G. Robert, Grégory Chagnon, Philippe Cinquin, Alexandre Moreau-Gaudry. Using a 3D needle-tissue force distribution basis to optimise the design of an instrumented needle. Computer Methods in Biomechanics and Biomedical Engineering, 2013, 16, pp.320-322. 10.1080/10255842.2013.815933 . hal-00963795

\section{HAL Id: hal-00963795 https://hal.science/hal-00963795}

Submitted on 25 Mar 2014

HAL is a multi-disciplinary open access archive for the deposit and dissemination of scientific research documents, whether they are published or not. The documents may come from teaching and research institutions in France or abroad, or from public or private research centers.
L'archive ouverte pluridisciplinaire HAL, est destinée au dépôt et à la diffusion de documents scientifiques de niveau recherche, publiés ou non, émanant des établissements d'enseignement et de recherche français ou étrangers, des laboratoires publics ou privés. 


\title{
Using a 3D Needle -Tissue Interaction Loading basis to optimize the design of an instrumented needle
}

\author{
A.L.G Robert*† and G. Chagnon $\uparrow$ and P. Cinquin $\uparrow$ and A. Moreau-Gaudry $\uparrow$ \\ † UJF-Grenoble, CNRS, TIMC-IMAG UMR5525, Grenoble, France
}

Keywords: Needle deformation; Load distribution; Instrumented needle; Optimal positioning of microgauges

\section{Introduction}

Many medical interventions are based on the insertion of needles to perform a diagnostic or therapeutic act. Such percutaneous insertions into soft tissues are one of the most common minimally invasive procedures. CT-guidance (Computerized Tomography) is a well-established technique for percutaneous procedures in order to obtain the needle and target positions. It enables to view any part of the body in three-dimensions and with typically higher definition than other imagery modalities.

During a CT-guided percutaneous procedure, the patient is moving in and out of the scanner in order to verify the good trajectory of the needle. It has to be noticed that the trajectory of the needle may be complex and not straight since the needle is brought to deform because of its interactions with inhomogeneous tissues and organs. That can involve a certain number of tests necessary to the installation of the needle which does not follow the planned trajectory. Furthermore, the amount of irradiation during procedures under CT-scan (patient and medical staff) can be high.

Methods in passive (imaging) [Dimaio, 2006] and active (instrumentation of the device) [Park, 2010] tracking of medical devices have been developed to improve the realization of the gesture.

Works in progress [Yang, 2010] raise the problems of incorporating strain microgauges on the needle. These microgauges provide information regarding the local deformations of the needle. In this paper, we describe a method enabling to optimally position the strain microgauges of an instrumented needle using a 3D loading basis, in order to explain the interaction forces applied on the needle during an intervention.

\section{Methods}

A needle model was developed [Robert, 2013a] to reconstruct the needle shape of a deformed needle from strain microgauges.

To find the optimal location of the microgauges, an optimization function was determined:

$$
\left(y_{\text {tip }}-S_{\text {tip }}\right)^{2}
$$

Where $\mathrm{y}$ is the needle reconstruction using Beam theory (referential) and $\mathrm{S}$ is the needle reconstruction using strain microgauges. $\mathrm{y}_{\text {tip }}$ and $\mathrm{S}_{\text {tip }}$ represent the values of these two reconstructions at the needle tip. The placement errors in the needle tip location are typically of the most concern.

Nevertheless, to use the Beam theory, the interaction forces between needle and tissue during a percutaneous procedure are to be known.

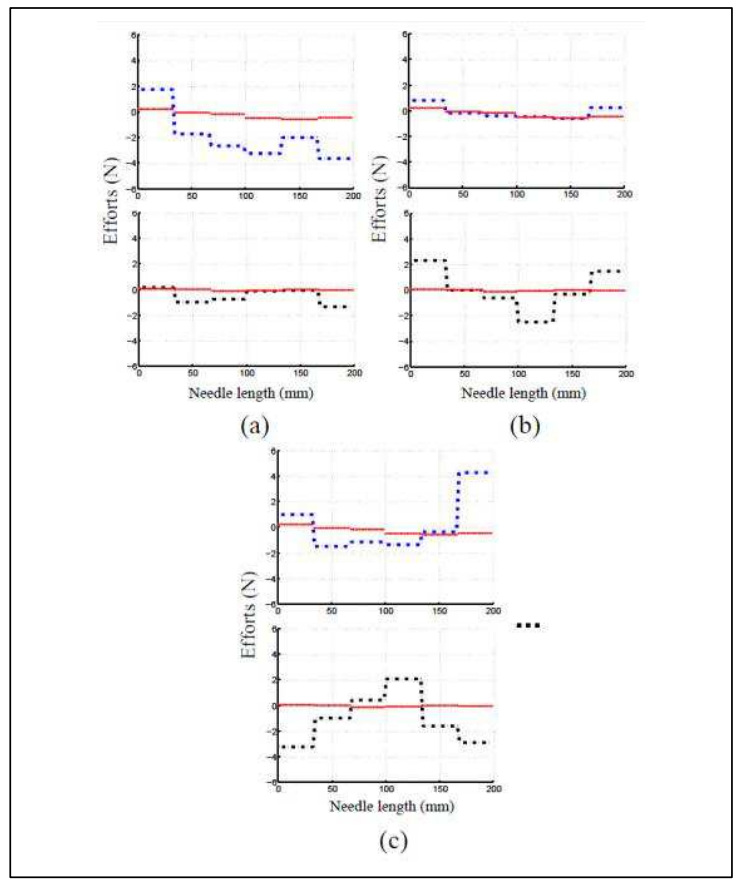

Figure 1 The first three loading modes. The efforts corresponding to these modes are represented.

To study the needle-tissue interactions, a generic 3D loading basis was determined [Robert, 2013b]. This loading basis was built from experiments on a fresh pig shoulder and validated on needles inserted during real clinical procedures. A 22-gauge needle with a length of $200 \mathrm{~mm}$ and the Young's modulus estimated at 200GPa was used. All needle deflections were modeled by using B-splines. Then, by associating the B-spline and beam theories, the bending moment and shear forces along each needle were computed. 
Finally, a statistical approach (Principal Component Analysis (PCA)) [Cootes, 2000] was employed to extract the relevant information from the set of deflections and to build the loading basis as shown in figure 1.

An algorithm is used to determine the optimal position of the microgauges. It attempts to find a constrained minimum of a scalar function (equation 1) of several variables starting at an initial estimate. Due to the manufacturing process, the number of microgauges is settled at two. The variables are then the two positions $\mathrm{G} 1$ and $\mathrm{G} 2$ of the microgauge 1 and 2, respectively.

\section{Results and Discussion}

The results of the optimal position are shown in figure 2 . The values of the optimization function are shown in gray depending of the two positions G1 and $\mathrm{G} 2$ of the strain microgauges. The position G1 is considered under the position G2. The results give a position $\mathrm{G} 1$ and $\mathrm{G} 2$ at $37 \mathrm{~mm}$ and $133 \mathrm{~mm}$ for a needle with a length of $200 \mathrm{~mm}$.

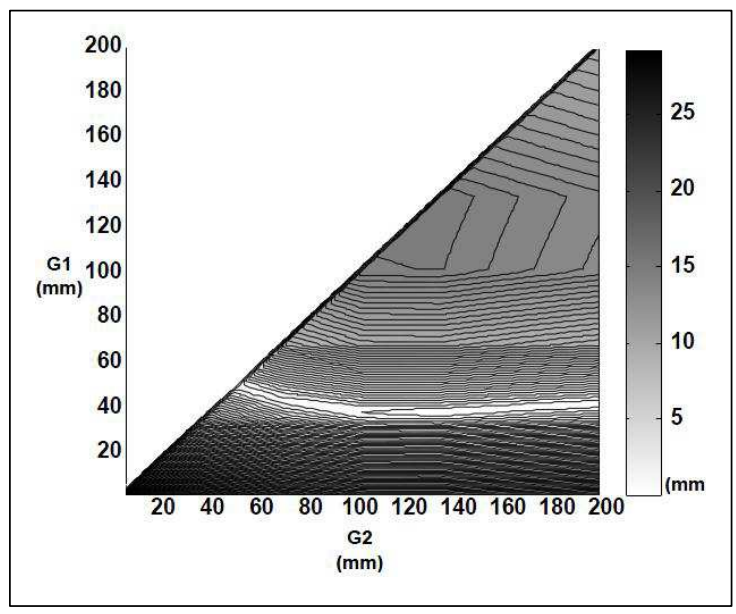

Figure 2 Reconstruction errors with all possible strain microgauges locations. The brighter region gives the lower errors.

The use of a 3D loading basis that acts on the needle during a medical procedure allows to determine an optimal position for the strain microgauges placed on the needle in order to track it.

This loading basis is generic enough to take into account most of the loading applied on needles during real clinical interventions. Thereby, the placement of strain microgauges takes accounts most of the possible deflection of the needles.

\section{Conclusions}

After the construction and the validation of the loading basis, this basis was used to determine an optimal position for the strain microgauges placed on a needle.

The knowledge of the interaction forces between needle and tissues may be useful to enrich techniques enabling to track in real time the motion of the needle with the aim of achieving a safer, less invasive and more efficient medical procedure.

\section{References}

Cootes T. 2000. An introduction to active shape models. Image processing and analysis, pp.223248.

Dimaio SP, Fischer GS, Maker SJ, Hata N, Iordachita I, Tempany CM, Kikinis R, Fichtinger G. 2006. A system for MRI-guided prostate interventions. International conference on Biomedical Robotics and Biomechatronics.

Park Y, Elayaperumal S, Daniel B, Ryu S, Shin M, Savall J, Black R, Moslehi B, Cutkosky M. 2010. Real-time estimation of 3-d needle shape and deflection for MRI-guided interventions. IEEE/ASME Transactions on Mechatronics, vol.15 (6), pp.906-915.

Robert ALG, Chagnon G, Bonvilain A, Cincuin P, Moreau-Gaudry A. 2013a. Toward a New Approach of Tracking of Medical Deformable Needle. International Congress and Exhibition of Computer Assisted Radiology and Surgery (CARS2013).

Robert ALG, Chagnon G, Bricault I, Cinquin P, Moreau-Gaudry A. 2013b. A Generic ThreeDimensional Static Loading Basis Linked to Surgical Needle Inserted into Complex Tissue. Journal of the Mechanical Behavior of Biomedical Materials, submitted.

Yang W, Bonvilain A, Alonso T, Moreau-Gaudry A, Basrour S. 2010. Modelling and characterization of an instrumented medical needle in sight of new microsensor design for its insertion guidance. Annual International Conference of the Engineering in Medicine and Biology Society (EMBC), pp.6465-6468. 